\title{
A STUDY ON THE EFFECTS OF FOLIAR FEEDING UNDER DIFFERENT SOIL FERTILIZATION CONDITIONS ON THE YIELD STRUCTURE AND QUALITY OF COMMON OAT (Avena sativa L.)
}

\author{
Stanisław Chwil \\ Department of Agricultural and Environmental Chemistry, University of Life Sciences in Lublin \\ Akademicka 15, 20-950 Lublin, Poland \\ e-mail: stanislaw.chwil@up.lublin
}

Received: 12.12.2013

\begin{abstract}
The present study was conducted based on a field experiment established on very acidic medium soil (silt loam). The experimental design included 4 soil fertilization treatments: $\mathrm{O}$, $\mathrm{NPK}, \mathrm{NPK}+\mathrm{MgSO}_{4} \cdot 7 \mathrm{H}_{2} \mathrm{O}, \mathrm{NPK}+\mathrm{CaO}+\mathrm{MgO}$, and 3 foliar feeding treatments: $\mathrm{O}_{(\mathrm{H} 2 \mathrm{O})}$, Insol $\mathrm{PK}+5 \%$ urea solution, Ekosol U. The test plant was the oat cultivar 'Kwant'. The aim of this study was to characterize in detail the response of oats to foliar feeding under the conditions of different soil fertilization with calcium and magnesium compounds. The experimental factors applied increased the yield parameters and differentiated the nutrient content in oat grain and straw. Soil fertilization had a greater effect on the quality parameters of primary yield than the foliar fertilizers used in the study. The best production and quality effects in growing oats were obtained after the application of $\mathrm{MgSO}_{4}$ and magnesium lime. Foliar feeding also affected beneficially the quantitative and qualitative characteristics of the yield. Among the fertilizers used, Insol PK showed a better effect than Ekosol U, in particular on the yield structure and the amino acid composition of proteins.
\end{abstract}

Key words: Avena sativa, foliar application, yield structure, macronutrients, crude protein, amino acids

\section{INTRODUCTION}

The oats acreage in Poland has decreased from year to year and in 2012 it was at a level of 543,000 ha with an average yield of $2.6 \mathrm{tha}^{-1}$. In spite of an increasing trend in oat yields in this area, there is still a large growth potential in relation to other Europe's oat producers. Oats is cultivated mainly for fodder purposes. Up to $20 \%$ of the world production is used in food industry uses. In our country, for consumption only $3 \%$ of the oats harvest is used, but this cereal crop is becoming more widely used in the production of healthy food, because it is a valuable source of dietary fiber. One of the most important criteria of the value of cereal grains is their protein content, since it determines their nutritive, feeding and technological values [1].

In addition to the growing qualities, fertilization, the basic aim of which is to meet the nutritional requirements of the crop plant, is an essential element of agricultural technology that determines the quantity and quality of final yield. Apart from basic nutrients (NPK), other elements showing yield-increasing effects, which include $\mathrm{Mg}, \mathrm{S}$ and micronutrients, are also used more and more frequently in fertilization under intensive plant production conditions [1, 2, 3, 4]. Plants take up nutrients mainly from the soil through the root system, but foliar application of nutrients has been gaining an increasing importance in recent years. For this purpose, an aqueous solution of urea or liquid, suspension or crystalline compound fertilizers are used to prepare solutions. These solutions are able to penetrate across the cuticle layer through the ectodesmata which are mainly located near the xylem and phloem bundles.

A major advantage of foliar feeding of plants is the speed of action and a high level of use of nutrients supplied $[5,6,7]$. Foliar applied nutrients are better used by plants compared to conventional soil application $[8,9,10]$. Foliar fertilizers can be used in combination with other agrochemicals [11], if only there are no manufacturer's contraindications and economic reasons and higher effectiveness of agents applied speak for that $[12,13]$. Foliar feeding of plants belongs to the most effective and at the same time most environmentally beneficial fertilization techniques $[14,15,16]$. 
The aim of the present study was to determine the effects of foliar feeding under the conditions of different soil fertilization with calcium and magnesium compounds on oat yield and quality.

\section{MATERIALS AND METHODS}

This study was carried out based on a threeyear field experiment on medium soil with a $\mathrm{pH}$ of 4.2 in 1 mole $\mathrm{KCl} . \mathrm{dm}^{-3}$ and with the granulometric composition of silt loam in Rudnik (50 53'23.9912”N $\left.22^{\circ} 57^{\prime} 59.8938^{\prime \prime} \mathrm{E}\right)$. This soil was characterized by a low content of available phosphorus and potassium as well as a very low content of sulfur and magnesium.

The experiment was conducted using a randomized block design in 3 replicates according to the following protocol: 1). Control treatment (spraying with water); 2). Insol PK + 5\% urea solution; 3). Ekosol U, relative to 4 soil fertilization treatments: 1 ). Control treatment (without fertilization); 2). NPK; 3). NPK + $\mathrm{MgSO}_{4} .7 \mathrm{H}_{2} \mathrm{O}$; 4). $\mathrm{NPK}+\mathrm{CaO}+\mathrm{MgO}$, in 3 replicates.

In $48 \mathrm{~m}^{2}$ plots in which the oat cultivar 'Kwant' was grown, mineral fertilization was used at a rate of $90 \mathrm{~kg} \mathrm{~N} \times \mathrm{ha}^{-1}, 38 \mathrm{~kg} \times \mathrm{P} \mathrm{ha}^{-1}, 108 \mathrm{~kg} \mathrm{~K} \times \mathrm{ha}^{-1}$ in the form of Polifoska 6-20-30 and ammonium nitrate as well as every year before sowing magnesium was applied at a rate of $19 \mathrm{~kg} \mathrm{Mg} \times \mathrm{ha}^{-1}$. Magnesium oxide lime was used in the first year of the experiment immediately after harvest of the previous crop according to single hydrolytic acidity. Foliar feeding was used 3 times during the growth period of oats at the stages of tillering, stem elongation and panicle emergence. In the treatments where plants were fed with Insol PK with the addition of urea, the rate of soil-applied nitrogen was reduced by $20.7 \mathrm{~kg} \mathrm{~N} \times \mathrm{ha}^{-1}$, since such an amount of this nutrient was supplied to the foliage using the spray liquid in the form of 5\% urea solution. In each soil fertilization treatment, the foliar fertilizers were used at the following rates: Insol PK $-6 \mathrm{dm}^{3} .300$ $\mathrm{dm}^{-3}$. ha ${ }^{-1}$ and Ekosol U $-2 \mathrm{dm}^{3} .300 \mathrm{dm}^{-3}$. ha ${ }^{-1}$. Insol PK contained (\%): P - 4.4; K - 15.8, whereas Ekosol $\mathrm{U}$ contained (\%): $\mathrm{N}-15 ; \mathrm{P}-2.2 ; \mathrm{K}-2.7 ; \mathrm{Na}-0.15$; $\mathrm{B}-0.01 ; \mathrm{Cu}-0.012 ; \mathrm{Fe}-0.012 ; \mathrm{Mn}-0.017 ; \mathrm{Mo}-$ $0.002, \mathrm{Zn}-0.1$.

After the plants were harvested, grain and straw yield were determined. Qualitative evaluation includes the following basic yield components: grain weight per panicle, number of panicles $\times \mathrm{m}^{-2}, 1000$ grain weight, number of grains per panicle. These traits were determined based on samples collected from $1 \mathrm{~m}^{2}$ in 3 replicates and subsequently the material obtained was used to prepare samples for laboratory analysis.

After mineralization in concentrated sulfuric acid with the addition of hydrogen peroxide, the following were determined in oat grain and straw: total
$\mathrm{N}$ by the Kjeldahl method, $\mathrm{K}, \mathrm{Ca}$ and $\mathrm{Mg}$ by AAS on a Hitachi Z-8200 polarized Zeeman atomic absorption spectrophotometer, $\mathrm{P}$ colorimetrically by the vanadium-molybdate method using a Cecil 2011 colorimeter. Total sulfur was determined according to B u t te r s $\mathrm{C}$ he nery [17]. The removal of macronutrients was calculated as the sum of a given nutrient in primary yield and straw based on the nutrient content in these organs. The qualitative evaluation of the yield showed the $\mathrm{K}:(\mathrm{Ca}+\mathrm{Mg})$ mole ratios and $\mathrm{N}: \mathrm{S}$ mass ratios, total protein content ( $\mathrm{N} \times 6.25)$, protein yield, and the amino acid composition of proteins. The grain amino acid content was determined by column chromatography using an Aminochrom II amino acid analyzer after hydrolysis in $6 \mathrm{M} \mathrm{HCl}$ at $110^{\circ} \mathrm{C}$ for $20 \mathrm{~h}$ according to the Davies and Thomas method [18]. Sulfur amino acids were determined according to Schramm and Moor method [19].

The total sum of amino acids, the sum of endogenous and exogenous amino acids as well as the limiting amino acid score for lysine, isoleucine and tryptophan were calculated. The limiting amino acid score (Chemical Score - CS) expresses the ratio of the exogenous limiting amino acid content in the tested protein to the content of this amino acid in the egg reference protein (WE).

The obtained results were evaluated by twoway analysis of variance and presented as means for the 3-year study period (1999-2001). Means were analyzed by Tukey's multiple comparisons at a significance level of 0.05 .

\section{RESULTS}

\section{Yield potential}

The experimental factors used differentiated the grain and straw yield as well as the basic yield components (Table 1). The foliar fertilizers increased the yield and basic yield components compared to the control treatment and only the variation in 1000 grain weight was below the level of significance. Out of the two fertilizers used in the study, Insol PK showed a better effect on the grain yield than Ekosol U, mostly by increasing the number of panicles $\times \mathrm{m}^{-2}$, number of kernels per panicle, and number of spikelets per panicle. The particular soil fertilization treatments also differentiated the yield and yield components. The grain and straw yield, 1000 grain weight and number of panicles had the highest values after the application of NPK with $\mathrm{CaO}+\mathrm{MgO}$ in fertilization, whereas magnesium sulfate $\mathrm{MgSO}_{4}$ had a beneficial effect on the number of spikelets and number of grains per panicle. The interaction of soil fertilization and foliar feeding had a significant impact on the straw yield and number of grains per panicle. 
Table 1

Grain and straw yield as well as the yield structure of foliar fertilized oats under different soil fertilization conditions

\begin{tabular}{|c|c|c|c|c|c|c|c|}
\hline \multirow{2}{*}{$\begin{array}{l}\text { Foliar fertilizer } \\
\text { (A) }\end{array}$} & \multirow{2}{*}{$\begin{array}{l}\text { Soil fertilization } \\
\text { (B) }\end{array}$} & $\begin{array}{l}\text { Grain } \\
\text { yield }\end{array}$ & $\begin{array}{l}\text { Straw } \\
\text { yield }\end{array}$ & $\begin{array}{l}\text { Thousand } \\
\text { grains weight }\end{array}$ & $\begin{array}{l}\text { Number of } \\
\text { panicles }\end{array}$ & $\begin{array}{l}\text { Number of } \\
\text { spikelets per } \\
\text { panicle }\end{array}$ & $\begin{array}{c}\text { Number of } \\
\text { grains per } \\
\text { panicle }\end{array}$ \\
\hline & & {$\left[\mathrm{t} \times \mathrm{ha}^{-1}\right]$} & {$\left[\mathrm{t} \times \mathrm{ha}^{-1}\right]$} & {$[\mathrm{g}]$} & $\begin{array}{l}\text { [pcs per square } \\
\text { metre] }\end{array}$ & [pcs] & [pcs] \\
\hline $\mathrm{H}_{2} \mathrm{O}$ & \multirow{3}{*}{ Control } & 3,47 & 5,03 & 29,67 & 348,41 & 21,97 & 31,54 \\
\hline Insol PK & & 3,75 & 5,65 & 30,71 & 387,50 & 24,53 & 35,27 \\
\hline Ekosol U & & 3,61 & 6,09 & 29,78 & 355,75 & 23,03 & 33,48 \\
\hline $\mathrm{H}_{2} \mathrm{O}$ & \multirow{3}{*}{ NPK } & 4,49 & 6,23 & 30,66 & 436,41 & 26,72 & 40,86 \\
\hline Insol PK & & 5,38 & 7,89 & 31,19 & 441,58 & 28,33 & 42,20 \\
\hline Ekosol U & & 5,27 & 7,78 & 31,42 & 423,33 & 27,46 & 39,65 \\
\hline $\mathrm{H}_{2} \mathrm{O}$ & \multirow{3}{*}{$\mathrm{NPK}+\mathrm{MgSO}_{4}$} & 4,86 & 6,79 & 30,42 & 429,58 & 28,16 & 41,62 \\
\hline Insol PK & & 5,63 & 7,81 & 30,15 & 445,91 & 31,41 & 47,50 \\
\hline Ekosol U & & 5,52 & 7,91 & 30,31 & 424,66 & 29,16 & 41,44 \\
\hline $\mathrm{H}_{2} \mathrm{O}$ & \multirow{3}{*}{$\mathrm{NPK}+\mathrm{CaO}+\mathrm{MgO}$} & 5,15 & 7,16 & 31,11 & 423,66 & 27,05 & 41,81 \\
\hline Insol PK & & 6,04 & 8,79 & 32,14 & 457,16 & 28,79 & 43,73 \\
\hline Ekosol U & & 5,53 & 7,79 & 32,66 & 427,33 & 28,86 & 43,75 \\
\hline \multirow[t]{2}{*}{$\mathrm{LSD}_{0,05}$ for $(\mathrm{AxB})$} & & n.s. & 1,09 & n.s. & n.s. & n.s. & 4,64 \\
\hline & Control & 3,61 & 5,59 & 30,05 & 363,89 & 23,18 & 33,43 \\
\hline \multirow[t]{3}{*}{ Mean } & NPK & 5,05 & 7,30 & 31,09 & 433,77 & 27,50 & 40,90 \\
\hline & $\mathrm{NPK}+\mathrm{MgSO}_{4}$ & 5,34 & 7,50 & 30,29 & 433,38 & 29,58 & 43,52 \\
\hline & $\mathrm{NPK}+\mathrm{CaO}+\mathrm{MgO}$ & 5,58 & 7,91 & 31,97 & 436,05 & 28,23 & 43,10 \\
\hline $\mathrm{LSD}_{0,05}$ for B & & 0,33 & 0,49 & 1,03 & 22,82 & 1,19 & 2,09 \\
\hline $\mathrm{H}_{2} \mathrm{O}$ & & 4,49 & 6,30 & 30,46 & 409,52 & 25,98 & 38,96 \\
\hline Insol PK & Mean & 5,20 & 7,53 & 31,05 & 433,04 & 28,26 & 42,17 \\
\hline Ekosol U & & 4,98 & 7,39 & 31,04 & 407,77 & 27,13 & 39,58 \\
\hline $\mathrm{LSD}_{0,05}$ for A & & 0,26 & 0,39 & n.s. & 18,04 & 0,93 & 1,65 \\
\hline
\end{tabular}

\section{The mineral composition of oat}

The fertilization treatments used significantly affected the macronutrient content in oat grain (Table 2). Ekosol U caused an increase in phosphorus content, while Insol PK increased the calcium content. Both Insol PK and Ekosol U decreased the sulfur content in oat grain. The nitrogen content was significantly higher in the analyzed samples collected from the plots in all soil fertilization treatments in relation to the control.

Fertilization with the addition of $\mathrm{CaO}+\mathrm{MgO}$ to the fertilizer dose significantly increased the calcium content compared to the other soil fertilization treatments. The lowest magnesium content in grain was found in the basic fertilization treatment (NPK), whereas the highest content of S and $\mathrm{K}$ as well as the lowest $\mathrm{P}$ content were obtained in the treatment with $\mathrm{MgSO}_{4}$.

Deacidification of soil also significantly increased the sulfur content compared to the control and basic fertilization treatments. The highest $\mathrm{N}$ content in grain, $\mathrm{P}$ and $\mathrm{Mg}$ content in grain and straw as well as $\mathrm{Ca}$ content in grain were obtained in this fertilization treatment. The interaction of soil fertilization and foliar feeding had a significant effect only on the sulfur content in oat grain.

The foliar fertilizers used caused a significant increase in the contents of macronutrients determined in straw (Table 3). Compared to the control treatment, only the potassium content was significantly lower than in the treatment with Ekosol U.

The nitrogen and potassium content in straw was higher in all soil fertilization treatments. A significantly higher content of phosphorus was found after the application of $\mathrm{NPK}+\mathrm{CaO}+\mathrm{MgO}$, while a higher magnesium content was found in the treatments where this component was added to the fertilizer dose. All soil fertilization treatments increased the sulfur content in straw, which reached the highest content in the treatment with $\mathrm{NPK}+\mathrm{MgSO}_{4}$. The interaction of the treatments used in the study significantly affected the contents of all macronutrients analyzed in straw. Feeding plants with Insol PK resulted in the highest removal of all macronutrients relative to the lowest values of this indicator in the control treatment (Table 4). 
Table 2

Macronutrient content in oat grain after application of foliar feeding under different soil fertilization conditions

\begin{tabular}{|c|c|c|c|c|c|c|c|}
\hline \multirow{2}{*}{ Foliar fertilizer (A) } & \multirow{2}{*}{ Soil fertilization (B) } & $\mathrm{N}$ & $\mathrm{P}$ & $\mathrm{K}$ & $\mathrm{Ca}$ & $\mathrm{Mg}$ & S \\
\hline & & \multicolumn{6}{|c|}{$\left[\mathrm{g} \times \mathrm{kg}^{-1}\right]$} \\
\hline $\mathrm{H}_{2} \mathrm{O}$ & \multirow{3}{*}{ Control } & 13.79 & 2.64 & 4.66 & 0.69 & 1.11 & 0.99 \\
\hline Insol PK & & 15.04 & 2.77 & 4.38 & 0.75 & 1.15 & 1.00 \\
\hline Ekosol U & & 14.89 & 2.99 & 4.45 & 0.65 & 1.20 & 0.84 \\
\hline $\mathrm{H}_{2} \mathrm{O}$ & \multirow{3}{*}{ NPK } & 16.53 & 2.58 & 4.18 & 0.61 & 0.99 & 1.21 \\
\hline Insol PK & & 16.32 & 2.74 & 4.70 & 0.77 & 1.07 & 1.02 \\
\hline Ekosol U & & 16.06 & 2.86 & 4.15 & 0.65 & 1.11 & 0.95 \\
\hline $\mathrm{H}_{2} \mathrm{O}$ & \multirow{3}{*}{$\mathrm{NPK}+\mathrm{MgSO}_{4}$} & 16.38 & 2.64 & 4.59 & 0.71 & 1.15 & 1.90 \\
\hline Insol PK & & 16.81 & 2.70 & 4.58 & 0.74 & 1.11 & 1.29 \\
\hline Ekosol U & & 16.13 & 2.82 & 4.30 & 0.74 & 1.15 & 1.39 \\
\hline $\mathrm{H}_{2} \mathrm{O}$ & \multirow{3}{*}{$\mathrm{NPK}+\mathrm{CaO}+\mathrm{MgO}$} & 17.22 & 2.78 & 4.56 & 0.77 & 1.20 & 1.19 \\
\hline Insol PK & & 16.17 & 2.87 & 4.50 & 0.91 & 1.14 & 1.06 \\
\hline Ekosol U & & 17.92 & 3.07 & 4.17 & 0.86 & 1.19 & 1.20 \\
\hline \multirow{2}{*}{$\mathrm{LSD}_{0,05}$ for $(\mathrm{AxB})$} & & n.s. & n.s. & n.s. & n.s. & n.s. & 0,22 \\
\hline & Control & 14.58 & 2.80 & 4.49 & 0.70 & 1.15 & 0.94 \\
\hline \multirow[t]{3}{*}{ Mean } & NPK & 16.30 & 2.73 & 4.34 & 0.68 & 1.05 & 1.06 \\
\hline & $\mathrm{NPK}+\mathrm{MgSO}_{4}$ & 16.44 & 2.72 & 4.49 & 0.73 & 1.14 & 1.53 \\
\hline & $\mathrm{NPK}+\mathrm{CaO}+\mathrm{MgO}$ & 17.10 & 2.91 & 4.41 & 0.85 & 1.18 & 1.15 \\
\hline $\mathrm{LSD}_{0,05}$ for $\mathrm{B}$ & \multirow{5}{*}{ Mean } & 0,97 & n.s. & n.s. & 0,07 & 0,1 & 0,10 \\
\hline $\mathrm{H}_{2} \mathrm{O}$ & & 15.98 & 2.66 & 4.50 & 0.69 & 1.11 & 1.32 \\
\hline Insol PK & & 16.08 & 2.77 & 4.54 & 0.79 & 1.12 & 1.09 \\
\hline Ekosol U & & 16.25 & 2.93 & 4.27 & 0.72 & 1.16 & 1.10 \\
\hline $\mathrm{LSD}_{0.05}$ for $\mathrm{A}$ & & n.s. & 0,20 & n.s. & 0,06 & n.s. & 0,08 \\
\hline
\end{tabular}

Table 3

Macronutrient content in oat straw after application of foliar feeding under different soil fertilization conditions

\begin{tabular}{|c|c|c|c|c|c|c|c|}
\hline \multirow{2}{*}{ Foliar fertilizer (A) } & \multirow{2}{*}{ Soil fertilization (B) } & $\mathrm{N}$ & $\mathrm{P}$ & $\mathrm{K}$ & $\mathrm{Ca}$ & $\mathrm{Mg}$ & S \\
\hline & & \multicolumn{6}{|c|}{$\left[\mathrm{g} \times \mathrm{kg}^{-1}\right]$} \\
\hline $\mathrm{H}_{2} \mathrm{O}$ & & 4.64 & 0.63 & 16.77 & 2.58 & 0.52 & 0.47 \\
\hline Insol PK & Control & 3.93 & 0.68 & 17.02 & 3.65 & 0.80 & 0.66 \\
\hline Ekosol U & & 4.20 & 0.68 & 14.73 & 4.02 & 0.58 & 0.65 \\
\hline $\mathrm{H}_{2} \mathrm{O}$ & & 9.35 & 0.54 & 18.66 & 2.69 & 0.61 & 0.74 \\
\hline Insol PK & NPK & 2.87 & 0.78 & 18.28 & 3.64 & 0.66 & 0.82 \\
\hline Ekosol U & & 4.37 & 0.68 & 16.62 & 3.87 & 0.70 & 0.80 \\
\hline $\mathrm{H}_{2} \mathrm{O}$ & & 8.32 & 0.66 & 17.20 & 2.56 & 0.78 & 0.97 \\
\hline Insol PK & $\mathrm{NPK}+\mathrm{MgSO}_{4}$ & 3.13 & 0.61 & 19.08 & 3.40 & 0.79 & 1.35 \\
\hline Ekosol U & & 4.44 & 0.75 & 17.36 & 3.79 & 0.92 & 1.21 \\
\hline $\mathrm{H}_{2} \mathrm{O}$ & & 7.78 & 0.78 & 17.81 & 3.13 & 1.07 & 0.65 \\
\hline Insol PK & $\mathrm{NPK}+\mathrm{CaO}+\mathrm{MgO}$ & 3.34 & 0.91 & 17.23 & 5.90 & 1.11 & 0.60 \\
\hline Ekosol U & & 5.02 & 1.07 & 17.16 & 4.11 & 0.90 & 0.50 \\
\hline \multirow[t]{2}{*}{$\mathrm{LSD}_{0,05}$ for $(\mathrm{AxB})$} & & 1,23 & 0,11 & 1,94 & 1,06 & 0,13 & 0,09 \\
\hline & Control & 4.26 & 0.66 & 16.17 & 3.42 & 0.63 & 0.59 \\
\hline \multirow[t]{3}{*}{ Mean } & NPK & 5.53 & 0.67 & 17.85 & 3.40 & 0.66 & 0.79 \\
\hline & $\mathrm{NPK}+\mathrm{MgSO}_{4}$ & 5.30 & 0.67 & 17.88 & 3.25 & 0.83 & 1.18 \\
\hline & $\mathrm{NPK}+\mathrm{CaO}+\mathrm{MgO}$ & 5.38 & 0.92 & 17.40 & 3.38 & 1.03 & 0.58 \\
\hline $\mathrm{LSD}_{0,05}$ for B & & 0,55 & 0,05 & 0,87 & n.s. & 0,06 & 0,04 \\
\hline $\mathrm{H}_{2} \mathrm{O}$ & & 4.77 & 0.65 & 17.61 & 2.74 & 0.74 & 0.71 \\
\hline Insol PK & Mean & 5.37 & 0.75 & 17.90 & 4.15 & 0.84 & 0.86 \\
\hline Ekosol U & & 5.21 & 0.79 & 16.47 & 3.95 & 0.78 & 0.80 \\
\hline $\mathrm{LSD}_{0,05}$ for $\mathrm{A}$ & & 0,43 & 0,04 & 0,69 & 0,37 & 0,05 & 0,03 \\
\hline
\end{tabular}


Table 4

Removal of macronutrient after application of foliar feeding of oats under different soil fertilization conditions

\begin{tabular}{|c|c|c|c|c|c|c|c|}
\hline \multirow{2}{*}{ Foliar fertilizer (A) } & \multirow{2}{*}{ Soil fertilization (B) } & $\mathrm{N}$ & $\mathrm{P}$ & $\mathrm{K}$ & $\mathrm{Ca}$ & $\mathrm{Mg}$ & $\mathrm{S}$ \\
\hline & & \multicolumn{6}{|c|}{$\left[\mathrm{kg} \times \mathrm{ha}^{-1}\right]$} \\
\hline $\mathrm{H}_{2} \mathrm{O}$ & & 64,26 & 12,00 & 100,02 & 15,35 & 6,39 & 5,66 \\
\hline Insol PK & Control & 85,73 & 14,05 & 134,59 & 23,50 & 8,64 & 7,36 \\
\hline Ekosol U & & 79,49 & 14,93 & 128,66 & 27,29 & 7,91 & 8,49 \\
\hline $\mathrm{H}_{2} \mathrm{O}$ & & 107,63 & 15,06 & 173,71 & 19,57 & 8,23 & 10,03 \\
\hline Insol PK & NPK & 129,88 & 20,81 & 204,36 & 32,50 & 10,59 & 11,72 \\
\hline Ekosol U & & 124,78 & 20,09 & 174,21 & 33,42 & 11,21 & 11,18 \\
\hline $\mathrm{H}_{2} \mathrm{O}$ & & 110,24 & 17,78 & 168,19 & 20,37 & 10,78 & 15,80 \\
\hline Insol PK & $\mathrm{NPK}+\mathrm{MgSO}_{4}$ & 131,08 & 19,92 & 200,57 & 29,18 & 11,93 & 13,38 \\
\hline Ekosol U & & 132,30 & 21,11 & 186,17 & 31,07 & 13,41 & 16,97 \\
\hline $\mathrm{H}_{2} \mathrm{O}$ & & 124,78 & 20,29 & 151,76 & 26,13 & 13,90 & 10,72 \\
\hline Insol PK & $\mathrm{NPK}+\mathrm{CaO}+\mathrm{MgO}$ & 141,74 & 25,23 & 211,02 & 55,85 & 16,03 & 11,69 \\
\hline Ekosol U & & 139,26 & 25,00 & 156,54 & 35,94 & 13,34 & 10,36 \\
\hline \multirow[t]{2}{*}{$\mathrm{LSD}_{0,05}$ for $(\mathrm{AxB})$} & & 23.32 & 3.95 & 39,64 & 5,90 & 2,12 & 2,54 \\
\hline & Control & 76,49 & 13,66 & 121,08 & 22,04 & 7,64 & 7,17 \\
\hline \multirow[t]{3}{*}{ Mean } & NPK & 120,76 & 18,65 & 184,09 & 28,50 & 10,01 & 10,97 \\
\hline & $\mathrm{NPK}+\mathrm{MgSO}_{4}$ & 124,54 & 19,60 & 184,98 & 26,87 & 12,04 & 16,72 \\
\hline & $\mathrm{NPK}+\mathrm{CaO}+\mathrm{MgO}$ & 135,27 & 23,51 & 173,11 & 39,31 & 14,42 & 10,92 \\
\hline $\mathrm{LSD}_{0,05}$ for B & & 10.47 & 1.77 & 17,80 & 2,65 & 0,95 & 1,14 \\
\hline $\mathrm{H}_{2} \mathrm{O}$ & & 101,73 & 16,28 & 148,42 & 20,35 & 9,82 & 10,55 \\
\hline Insol PK & Mean & 122,11 & 20,00 & 187,64 & 35,26 & 11,80 & 12,04 \\
\hline Ekosol U & & 118,96 & 20,28 & 161,39 & 31,93 & 11,47 & 11,75 \\
\hline $\mathrm{LSD}_{0,05}$ for $\mathrm{A}$ & & 8.24 & 1.40 & 14,01 & 2,08 & 0,75 & 0,90 \\
\hline
\end{tabular}

The lowest values of nutrient removal, significantly differing from the other soil fertilization treatments, were found in the control treatment without fertilization. The highest macronutrient contents were generally observed in samples from the treatment with $\mathrm{NPK}+\mathrm{CaO}+\mathrm{MgO}$, and only the amounts of potassium and sulfur were highest after the application of $\mathrm{NPK}+\mathrm{MgSO}_{4}$. The interaction of foliar feeding and soil fertilization had a significant effect on the removal of all nutrients analyzed in the study.

\section{Yield quality parameters}

In the present study, foliar feeding practices were of little importance for differentiating the protein content in oat grain compared to the soil fertilization treatments used and this trait had the highest value in the treatment with NPK $+\mathrm{CaO}+\mathrm{MgO}$ (Table 5). Among the foliar fertilizers used, Insol PK increased the protein yield by $16.5 \%$, while Ekosol U by $12.8 \%$. Such a high increase in protein yield results from the beneficial effects of the foliar fertilizers used not only on the oat grain yield, but also on the grain protein content. Soil fertilization also had a greater influence on the protein yield than the foliar fertilizers, since all its treatments increased the protein yield compared to the con- trol, with the highest value in the treatment with NPK $+\mathrm{CaO}+\mathrm{MgO}$ (Table 5). The value of the $\mathrm{K}:(\mathrm{Ca}+\mathrm{Mg})$ ratio in straw was in the optimal range $(1.6-2.1: 1)$ in all soil fertilization and foliar feeding treatments; this range was minimally exceeded in the treatment with water spraying. The value of the $\mathrm{K}:(\mathrm{Ca}+\mathrm{Mg})$ ratio in grain, much lower from the minimum value (1.6), does not result from a disturbance in the balance between these nutrients but from a naturally low content of potassium in the generative organs which contain reserve substances. The use of foliar fertilizers caused the $\mathrm{N}: \mathrm{S}$ ratio in grain to widen, whereas among the soil fertilization treatments only $\mathrm{NPK}+\mathrm{MgSO}_{4}$ distinctly decreased the $\mathrm{N}: \mathrm{S}$ ratio (Table 5).

Insol PK increased the content of endogenous and exogenous amino acids and beneficially affected the value of the quality parameter calculated for tryptophan (Table 6). After the application of Ekosol U, the endogenous amino acid content was at the level found in the control treatment and the proportion of exogenous amino acids (E/T) increased, but Ekosol U decreased the value of this quality parameter for lysine. A higher value of valine and histidine compared to the reference was found under the influence of Insol PK application. 
Table 5

Quality parameters of oat after application of foliar feeding under different soil fertilization conditions

\begin{tabular}{|c|c|c|c|c|c|c|c|}
\hline \multirow{2}{*}{$\begin{array}{l}\text { Foliar fertilizer } \\
\text { (A) }\end{array}$} & \multirow{2}{*}{$\begin{array}{l}\text { Soil fertilization } \\
\text { (B) }\end{array}$} & Total protein $(\mathrm{N} \times 6,25)$ & Protein yield & \multirow{2}{*}{$\begin{array}{l}\mathrm{K} / \mathrm{Ca}+\mathrm{Mg} \\
\text { in grain }\end{array}$} & \multirow{2}{*}{$\begin{array}{l}\mathrm{K} / \mathrm{Ca}+\mathrm{Mg} \\
\text { in straw }\end{array}$} & \multirow{2}{*}{$\begin{array}{c}\mathrm{N} / \mathrm{S} \\
\text { in grain }\end{array}$} & \multirow{2}{*}{$\begin{array}{c}\mathrm{N} / \mathrm{S} \\
\text { in straw }\end{array}$} \\
\hline & & {$\left[\mathrm{g} \times \mathrm{kg}^{-1}\right]$} & {$\left[\mathrm{kg} \times \mathrm{ha}^{-1}\right]$} & & & & \\
\hline $\mathrm{H}_{2} \mathrm{O}$ & \multirow{3}{*}{ Control } & 86,21 & 289,88 & 6,67 & 11,30 & 13,9 & 9,9 \\
\hline Insol PK & & 94,02 & 353,68 & 5,90 & 8,03 & 15,0 & 6,0 \\
\hline Ekosol U & & 93,06 & 335,94 & 6,30 & 6,57 & 17,7 & 6,5 \\
\hline $\mathrm{H}_{2} \mathrm{O}$ & \multirow{3}{*}{ NPK } & 103,29 & 462,20 & 6,73 & 11,90 & 13,7 & 12,6 \\
\hline Insol PK & & 102,00 & 537,62 & 6,46 & 8,83 & 16,0 & 3,5 \\
\hline Ekosol U & & 100,38 & 518,31 & 6,12 & 7,55 & 16,9 & 5,5 \\
\hline $\mathrm{H}_{2} \mathrm{O}$ & \multirow{3}{*}{$\mathrm{NPK}+\mathrm{MgSO}_{4}$} & 101,86 & 489,95 & 6,36 & 11,06 & 8,6 & 8,6 \\
\hline Insol PK & & 105,04 & 568,85 & 6,32 & 9,60 & 13,0 & 2,3 \\
\hline Ekosol U & & 100,79 & 545,36 & 5,83 & 7,79 & 11,6 & 3,7 \\
\hline $\mathrm{H}_{2} \mathrm{O}$ & \multirow{3}{*}{$\mathrm{NPK}+\mathrm{CaO}+\mathrm{MgO}$} & 107,61 & 551,47 & 5,94 & 9,19 & 14,5 & 12,0 \\
\hline Insol PK & & 101,08 & 585,00 & 5,48 & 5,11 & 15,2 & 5,6 \\
\hline Ekosol U & & 112,00 & 605,87 & 5,14 & 7,19 & 14,9 & 10,0 \\
\hline \multirow[t]{2}{*}{$\mathrm{LSD}_{0,05}$ for $(\mathrm{AxB})$} & & 13,46 & 113,24 & - & - & - & - \\
\hline & Control & 91,10 & 326,51 & 6,26 & 8,30 & 15,5 & 7,2 \\
\hline \multirow[t]{3}{*}{ Mean } & NPK & 101,89 & 506,00 & 6,43 & 9,16 & 15,4 & 7,0 \\
\hline & $\mathrm{NPK}+\mathrm{MgSO}_{4}$ & 102,57 & 534,72 & 6,16 & 9,29 & 10,7 & 4,5 \\
\hline & $\mathrm{NPK}+\mathrm{CaO}+\mathrm{MgO}$ & 106,90 & 580,78 & 5,49 & 8,48 & 14,9 & 9,3 \\
\hline $\mathrm{LSD}_{0,05}$ for $\mathrm{B}$ & \multirow{5}{*}{ Mean } & 6,04 & n.s & - & - & - & - \\
\hline $\mathrm{H}_{2} \mathrm{O}$ & & 99,74 & 448,37 & 6,44 & 10,77 & 12,1 & 6,7 \\
\hline Insol PK & & 100,54 & 511,29 & 6,03 & 7,49 & 14,7 & 6,2 \\
\hline Ekosol U & & 101,56 & 501,37 & 5,85 & 7,26 & 14,8 & 6,5 \\
\hline $\mathrm{LSD}_{0,05}$ for $\mathrm{A}$ & & 4,76 & n.s. & - & - & - & - \\
\hline
\end{tabular}

Table 6

Effect of foliar feeding on the amino acid composition of oat grain protein

\begin{tabular}{|c|c|c|c|c|}
\hline Amino acid & $\mathrm{H}_{2} \mathrm{O}$ & Insol PK & Ekosol U & WE - whole egg protein standards \\
\hline \multicolumn{5}{|c|}{ Non-essential amino acids $\mathrm{g} / 100 \mathrm{~g}$ protein } \\
\hline Asp & 7,3 & 8,2 & 6,8 & \\
\hline Ser & 4,4 & 5,0 & 4,5 & \\
\hline Glu & 18,4 & 22,4 & 17,9 & \\
\hline Gly & 4,7 & 6,1 & 4,9 & \\
\hline Ala & 4,6 & 5,5 & 4,9 & \\
\hline Tyr & 2,5 & 2,8 & 3,0 & \\
\hline Cys & 2,7 & 2,9 & 2,7 & \\
\hline$\Sigma$ & 44,6 & 52,9 & 44,7 & \\
\hline \multicolumn{5}{|c|}{ Essential amino acids $\mathrm{g} / 100 \mathrm{~g}$ protein } \\
\hline Met + Cys & 4,1 & 4,4 & 4,1 & 5,7 \\
\hline Phe + Tyr & 7,2 & 7,6 & 7,8 & 9,3 \\
\hline Val & 5,1 & 7,1 & 6,5 & 6,6 \\
\hline Ile & 3,3 & 3,8 & 3,8 & 5,4 \\
\hline Leu & 6,6 & 7,0 & 6,7 & 8,6 \\
\hline Phe & 4,7 & 4,8 & 4,8 & \\
\hline Lys & 4,1 & 4,1 & 3 & 7,0 \\
\hline His & 3,0 & 2,5 & 2,1 & 2,2 \\
\hline Arg & 4,7 & 5,0 & 4,9 & \\
\hline Met & 1,4 & 1,5 & 1,4 & \\
\hline $\operatorname{Trp}$ & 0,6 & 0,7 & 0,6 & 1,7 \\
\hline Thr & 3,1 & 3,6 & 3,1 & 4,7 \\
\hline$\Sigma$ & 36,6 & 40,1 & 37,5 & \\
\hline$\Sigma \mathrm{AA}$ & 81,2 & 93,0 & 82,2 & \\
\hline $\mathrm{E} / \mathrm{T}$ & 45,1 & 43,1 & 45,6 & \\
\hline CS (WE)Trp & 35,3 & 41,2 & 35,3 & \\
\hline CS (WE)Lys & 58,6 & 58,6 & 51,4 & \\
\hline CS (WE)Ile & 61,1 & 70,4 & 70,4 & \\
\hline
\end{tabular}

AA - total amino acid; E/T - essential amino acid participation; CS - chemical score of restrictive amino acid; WE - whole egg protein standards 
Relative to the control treatment, soil fertilization caused a decrease in the proportion of exogenous amino acids in protein. The application of $\mathrm{NPK}+\mathrm{MgSO}_{4}$ and $\mathrm{NPK}+\mathrm{CaO}+\mathrm{MgO}$ in soil fertilization contributed to obtaining the highest contents of endogenous and exogenous amino acids after the application of NPK + $\mathrm{CaO}+\mathrm{MgO}$ fertilization (Table 7). When NPK $+\mathrm{CaO}$ $+\mathrm{MgO}$ fertilization was used, a higher content of va- line compared to the reference and the highest value of the quality parameter for lysine were obtained. A decrease in isoleucine was found in the treatments NPK $+\mathrm{MgSO}_{4}$ and $\mathrm{NPK}+\mathrm{CaO}+\mathrm{MgO}$, whereas the highest content of this component was obtained in the basic soil fertilization treatment (NPK). In the treatment NPK + $\mathrm{MgSO}_{4}$, the highest content of sulfur amino acids was found.

Table 7

Effect of soil fertilization on the amino acid composition of oat grain protein

\begin{tabular}{|c|c|c|c|c|c|}
\hline Amino acid & Control & NPK & $\mathrm{NPK}+\mathrm{MgSO}_{4}$ & $\mathrm{NPK}+\mathrm{CaO}$ i $\mathrm{MgO}$ & WE - whole egg protein standards \\
\hline \multicolumn{6}{|c|}{ Non-essential amino acids $\mathrm{g} / 100 \mathrm{~g}$ protein } \\
\hline Asp & 6,5 & 7,2 & 8,5 & 7,3 & \\
\hline Ser & 4,3 & 4,5 & 5,0 & 4,7 & \\
\hline Glu & 17,9 & 18,7 & 21,0 & 20,7 & \\
\hline Gly & 4,7 & 4,9 & 5,6 & 5,8 & \\
\hline Ala & 4,3 & 4,7 & 5,3 & 5,5 & \\
\hline Tyr & 2,8 & 2,8 & 2,4 & 2,9 & \\
\hline Cys & 2,8 & 2,7 & 2,8 & 2,7 & \\
\hline$\Sigma$ & 43,3 & 45,5 & 50,6 & 49,6 & \\
\hline \multicolumn{6}{|c|}{ Essential amino acids $\mathrm{g} / 100 \mathrm{~g}$ protein } \\
\hline Met + Cys & 4,1 & 4,0 & 4,3 & 4,2 & 5,7 \\
\hline Phe + Tyr & 7,6 & 7,3 & 7,0 & 8,0 & 9,3 \\
\hline Val & 6,0 & 6,3 & 5,7 & 6,9 & 6,6 \\
\hline Ile & 3,9 & 4,3 & 3,1 & 3,4 & 5,4 \\
\hline Leu & 6,6 & 7,0 & 6,8 & 6,7 & 8,6 \\
\hline Phe & 4,8 & 4,5 & 4,6 & 5,1 & \\
\hline Lys & 3,7 & 3,9 & 3,9 & 4,2 & 7,0 \\
\hline His & 2,5 & 2,6 & 2,4 & 2,5 & 2,2 \\
\hline Arg & 5,0 & 4,4 & 5,1 & 4,8 & \\
\hline Met & 1,3 & 1,3 & 1,5 & 1,5 & \\
\hline Trp & 0,6 & 0,6 & 0,7 & 0,7 & 1,7 \\
\hline Thr & 3,0 & 3,2 & 3,5 & 3,4 & 4,7 \\
\hline$\Sigma$ & 37,4 & 38,1 & 37,3 & 39,2 & \\
\hline$\Sigma \mathrm{AA}$ & 80,7 & 83,6 & 87,9 & 88,8 & \\
\hline $\mathrm{E} / \mathrm{T}$ & 46,3 & 45,6 & 42,4 & 44,1 & \\
\hline CS (WE)Trp & 35,3 & 35,3 & 41,2 & 41,2 & \\
\hline CS (WE)Lys & 52,8 & 55,7 & 55,7 & 60,0 & \\
\hline CS (WE)Ile & 72,2 & 79,6 & 57,4 & 63,0 & \\
\hline
\end{tabular}

AA - total amino acid; E/T - essential amino acid participation; CS - chemical score of restrictive amino acid; WE whole egg protein standards

\section{DISCUSSION}

\section{Yield potential}

Numerous studies show the beneficial effect of foliar application of nutrients on the yield of crop plants and their quality parameters $[1,2,20]$. The foliar fertilizers used in the present research increased the grain and straw yield, which is confirmed by other studies $[20,21]$. The variation in the oat grain yield components was more dependent on soil fertilization used than on foliar feeding of plants. The oat belongs to plants that tolerate a high degree of soil acidification, but it responds favorably to liming of very acidic soils [22]. Furthermore, it should be noted that magnesium lime was used in this study, which increased the beneficial effect of soil deacidification, since oats have higher requirements for this nutrient than other cereals $[22,23]$.

\section{The mineral composition}

Foliar feeding influenced the macronutrient content in oat grain to a lesser extent than soil fertilization. 
This was related to the greater stability of the mineral composition of the generative organs, which mainly accumulate reserve materials in the form of organic compounds poor in potassium, unlike the vegetative parts, as well as to the small amount of nutrients supplied with the foliar fertilizers. The variation in the content of $\mathrm{N}, \mathrm{P}$ and $\mathrm{Ca}$ in oat grain was not associated only with their penetration through the aerial part, but it also resulted from their higher uptake from the soil. The research using combinations of foliar fertilizers has shown their beneficial effects on increasing the rate of uptake and use of nutrients from the substrate $[2,24]$. The activation of physiological processes such as photosynthesis, transpiration and respiration as a result of foliar supplied nutrients causes an increased demand of plant biomass for soil nutrients [25, 26]. A rise in the transpiration rate also increases nutrient uptake by increasing the suction force of the roots and the speed of movement of ions transported through the conductive tissues, while the respiration of plants is a source of energy necessary for transporting ions taken up by the root system $[27,28$, 29].

Foliar feeding differentiated to a greater extent the macronutrient content in straw than in oat grain similar correlations have been found in other studies $[24,30]$.

The used soil fertilization treatments differentiated the content of $\mathrm{N}, \mathrm{Ca}, \mathrm{Mg}$ and $\mathrm{S}$ in grain. Fertilization with the addition of $\mathrm{MgSO}_{4}$ to the fertilizer dose increased the sulfur content in grain and straw, but decreased the P content in oat grain, which is in agreement with other results [31,32]. The highest total $\mathrm{S}$ content in grain and straw was obtained in the treatment with $\mathrm{MgSO}_{4}$ in the fertilizer mix, which has been shown in other studies [31,33]. Sulfur deficiency in the soil results in a disturbance in basic physiological processes of the plant, primarily by reducing the photosynthesis rate, protein synthesis and nucleic acid content [34]. A higher content of $\mathrm{K}, \mathrm{Ca}$ and $\mathrm{Mg}$ in the treatment with $\mathrm{S}$ use in fertilization, compared to basic NPK fertilization, should be explained by the synergism of these cations in relation to $\mathrm{SO}_{4}{ }^{2-}$ anions taken up by the plant $[32,35,36,37]$. The lower $\mathrm{N}$ content in this fertilization treatment was associated with the antagonistic effects of $\mathrm{SO}_{4}{ }^{2-}$ ions in relation to $\mathrm{NO}_{3}{ }^{-}$ ions [31].

The increase in the content of $\mathrm{N}, \mathrm{Ca}, \mathrm{Mg}$ and $\mathrm{S}$ as affected by liming results from the conversion of these nutrients into available forms, because liming of acidic soils increases the soil availability of macronutrients and improves their use by crop plants [22]. Kozłowska [31] also showed an increase in $\mathrm{Ca}$ and $\mathrm{Mg}$ content in oat grain and straw after the application of $\mathrm{CaCO}_{3}$. Apart from $\mathrm{N}, \mathrm{Ca}$ and $\mathrm{Mg}$, liming also increased the content of $\mathrm{P}$ in straw, the availability of which is limited under acidic soil $\mathrm{pH}$ conditions due to its binding to $\mathrm{Al}^{3+}$ and $\mathrm{Fe}^{3+}$ ions in the form of sparingly soluble compounds [38].

As a result of foliar feeding with Insol PK, the highest values of nutrient removal were found for all nutrients analyzed in primary and secondary yield. Other studies also indicate higher nutrient removal as influenced by foliar feeding of plants $[2,24]$. On the other hand, the highest removal of N, P, Ca and Mg was obtained in the liming treatment, since the availability of these nutrients increases with decreased soil acidity.

\section{Yield quality parameters}

Numerous studies have shown a beneficial effect of foliar application of micronutrients as well as of $\mathrm{N}$ and $\mathrm{Mg}$ among macronutrients on protein yield $[1,2]$, but in the present study the increase in protein content as affected by foliar feeding was below the level of significance. The protein yield was more associated with the influence of foliar fertilizers on the grain yield than on the protein content in oat grain.

The $\mathrm{N}: \mathrm{S}$ ratio in grain was in the optimal range of $10-15: 1[39,40,41]$. Its higher values in the treatments poor in sulfur resulted from the lack of possibility to transfer $\mathrm{SO}_{4}{ }^{2-}$ ions from the older vegetative organs of the plant to the younger developing generative organs [42]. The $\mathrm{K}:(\mathrm{Ca}+\mathrm{Mg})$ ratio was in the optimal range. Among the fertilization factors applied, foliar feeding narrowed the values of the $\mathrm{K}:(\mathrm{Ca}+\mathrm{Mg})$ ratio in oat grain and straw, while the soil fertilization treatments used widened its value compared to the control treatment.

A valued property of oat protein is its high level of exogenous amino acids with a stable amino acid composition, regardless of its content in grain [43, 44]. According to the literature reports, isoleucine can be considered to be an amino acid that reduces the nutritional value of cereal protein [45, 46, 47], but in the present study lower values were found for lysine and tryptophan, aside from isoleucine. Despite that soil fertilization had a greater impact on the yield quality parameters than foliar fertilizers, foliar feeding should also be considered to be an agronomic practice that beneficially affects the amino acid composition of protein in oat grain.

\section{CONCLUSIONS}

1. Foliar feeding and soil fertilization increased the grain and straw yield of oat and had a beneficial effect on the yield components, but use of foliar fertilizers slightly differentiated the macronutrient content in oat grain.

2. Feeding oat plants with Insol PK resulted in the highest removal of all macronutrients analyzed, but 
the differences were small in relation to the treatment with Ekosol U application, where as highest removal of $\mathrm{N}, \mathrm{P}, \mathrm{Ca}$, and $\mathrm{Mg}$ was found under the influence of liming, while the treatment with the use of $\mathrm{MgSO}_{4}$ had the greatest effect on the removal of $\mathrm{K}$ and $\mathrm{S}$.

3. The foliar fertilizers showed a similar and small effect on the basic quality parameters of oat, but a by far higher yield of protein was obtained under the influence of Insol PK.

4. Soil fertilization exerted a greater effect on the quality parameters of oat than foliar feeding. The highest protein content and yield were found in the liming treatment.

5. Foliar feeding beneficially affected the biological value of protein; among the fertilizers used, Insol PK increased the values of CS, whereas Ekosol U the proportion of exogenous amino acids.

\section{Acknowledgements}

This research was supported by the Ministry of Science and Higher Education of Poland as part of the statutory activities of the Department of Agricultural and Environmental Chemistry, University of Life Sciences in Lublin.

\section{REFERENCES}

1. Barczak B, Kozera W, Nowak K, Majcherc z a k E. Wpływ nawożenia saletrą amonową z mikroelementami na plon ziarna i białka owsa odmiany Komes. Biul Inst Hod Aklim Rośl. 2006; 239: 19-25.

2. Chwil S. The effect of magnesium and nitrogen on the quality parameters of winter wheat yield. Ann Univ Mariae Curie-Skłodowska, E Agric. 2009; 64(2): 61-66.

3. Chwil S. Wpływ intensywności nawożenia mineralnego na plon pszenicy ozimej oraz zawartość magnezu w glebie i roślinie. Biul Magnez. 2000; 5(4): 278-283.

4. Zengin M, Gökmen F, Yazici MA, Gezgin $\mathrm{S}$. Effects of potassium, magnesium, and sulphur containing fertilizers on yield and quality of sugar beets (Beta vulgaris L.). Turk J Agric For. 2009; 33: 495-502.

5. Faber A, Kęsik K. Ocena skuteczności krajowych wieloskładnikowych nawozów dolistnych w doświadczeniach wazonowych i polowych. Materiały Seminarium Naukowego, Dolistne dokarmianie i ochrona roślin w świetle badań i doświadczeń praktyki rolniczej, Puławy, 13-14 grudnia. 1988: 170-179.

6. Sa dowski H, Wiśniewski K. Skuteczność dolistnego nawożenia buraków cukrowych. Biul Inst Hod Aklim Rośl. 1991; 177: 63-69.

7. Boligłowa E. Wpływ dolistnego dokarmiania na zawartość niektórych mikroelementów w bulwach ziemniaka. Zesz Probl Postęp Nauk Roln. 1996; 434: 163-167.

8. Skiba T. Wstępne obserwacje nad dolistnym stosowaniem mocznika na zboża w doświadczeniu wazonowym.
Materiały Seminarium Naukowego „Dolistne dokarmianie i ochrona roślin w świetle badań i doświadczeń praktyki rolniczej” Puławy, 13-14 grudnia. 1988: 57-75.

9. Grzebisz W, Gaj R. Zbilansowane nawożenie rzepaku ozimego. W: W. Grzebisz (red). Zbilansowane nawożenie rzepaku - aktualne problemy. Wyd AR Poznań, 2000: 83-98.

10. Ko c oń A. Efektywność wykorzystania azotu z mocznika stosowanego dolistnie i doglebowo przez pszenicę ozimą i bobik. Acta Agroph. 2003; 85: 55-63.

11. Drzewiecki S, Pietryga J. Wpływ łącznego stosowania regulatora wzrostu Terpal C 460 SL z nawozami dolistnymi na cechy jakościowe ziarna pszenicy ozimej. Prog Plant Prot. 2003; 43(2): 595-597.

12. Szewczuk C, Michałojć Z. Praktyczne aspekty dolistnego dokarmiania roślin. Acta Agroph. 2003; 85: 19-29.

13. Hu Y, Burcus Z, Schmidhalter U. Effect of foliar fertilization application on the growth and mineral nutrient content of maize seedlings under drought and salinity. Soil Sci Plant Nutr. 2008; 54: 133-141. http://dx.doi.org/ 10.1111/j.1747-0765.2007.00224.x

14. Rogalski L. Studium integrowania zabiegów ochrony z dolistnym dokarmianiem roślin w aspekcie ekologicznym. Post Nauk Roln. 1992; 1: 97-105.

15. Fageria NK, Barbosa Filho MP, Moreira A, Guimarães CM. Foliar fertilization of crop plants. J Plant Nutr. 2009; 32: 1044-1064. http://dx.doi.org/10.10 80/01904160902872826

16. Hoy tova D. 2013. A review of foliar fertilization of some vegetables crops. Ann Re Res Biol. 2013; 3(4): 455-465.

17. Now o s i els k i O. Metody oznaczania potrzeb nawożenia. PWRiL, Warszawa 1974.

18. Davies MG, Thomas A J. An investigation of hydrolytic techniques for the amino acid analysis of foodstuffs. J. Sci. Food Agric. 1973; 24(12): 1525-1540. http://dx.doi. org/10.1002/jsfa.2740241208

19. W i e r c ińs k i J . Ogólne zasady przygotowania materiału biologicznego do analizy składników chemicznych instrumentalnymi metodami Centralnego Laboratorium Aparaturowego CLA. Lublin 1984.

20. Chwil S. Plonowanie pszenicy ozimej pod wpływem dolistnego dokarmiania wieloskładnikowym nawozem Wuxal top $\mathrm{N}$ w warunkach zróżnicowanego nawożenia azotem. Rocz Glebozn. 2000; 51(3/4): 129-134.

21. Tobiasz-Salach R, Bobrecka-Jamro D, Szpunar-Krok E. Wpływ dolistnego dokarmiania na plon i skład chemiczny ziarna owsa. Biuletyn Instytutu Hodowli i Aklimatyzacji Roślin 2007; 246: 55-60.

22. Eabuda S, Filipek T, Dechnik I. Reakcja owsa na zróżnicowane formy wapnia i magnezu w doświadczeniu modelowym. Rocz Glebozn. 1992; 43: 29-35.

23. Błaziak J. Ocena zmian zawartości mikroelementów w zbożach pod wpływem wapnowania i magnesowania gleby. Ann Univ Mariae Curie-Skłodowska, E Agric. 2007; 62(1): 77-84.

24. Kulczycki G, Januszkiewicz R, Jachymczak A. The effect of foliar applied fertilizer Ekolist on the yield 
and chemical composition of spring wheat. Zesz Nauk Uniw Przyr we Wrocławiu, Rolnictwo. 2009; 45(574): 19-28.

25. Michałek S, Chwil S, Pranagal J, Ligęza S. Wczesny wzrost kukurydzy w warunkach dolistnego dokarmiania nawozami Viflo. Zesz Probl Post Nauk Rol, 2009; 542: 333-339.

26. Michałek S, Chwil S, Pranagal J, Ligęza S. Wpływ dolistnych nawozów Viflo na wymianę gazową liści, fluorescencję oraz początkowy wzrost bobu (Vica faba L. odm. Maior). Zesz Probl Post Nauk Rol. 2009; 542: 341-148.

27. Hopmans JW, Bristow KL. Current capabilities and future needs of root water and nutrient uptake modeling. Adv Agron. 2002; 77: 103-183. http://dx.doi.org/10.1016/ S0065-2113(02)77014-4

28. Chavarria G, Santos HP. Plant Water Relations: Absorption, Transport and Control Mechanisms. In: Montanaro G, Dichio B (eds.) Advances in Selected Plant Physiology Aspects. Rijeka: InTech. 2012: 105-132. http://dx. doi.org/10.5772/33478

29. Kutrowska A. Roślinne transportery błonowe metali Śladowych. Kosmos. 2013, 62(1):105-113.

30. Nogalska A, Czapla J, Klasa A. Application of complex fertilizers in oats. EJPAU Agronomy. 2012; 15(2): 1-6. Available Online http://www.ejpau.media.pl

31. Kozłowska J. Bezpośredni i następczy wpływ nawożenia siarką i wapnowania na zmiany w składzie jonowym roślin. Chem Inż Ekol. 2000; 7(6): 575-591.

32. Podleśna A. Wpływ nawożenia siarka na zawartość i pobranie składników pokarmowych przez rzepak ozimy. Rośliny oleiste. 2004; 25: 627-636.

33. B a rc zak B, Now a k K. Zawartość makroskładników oraz ich stosunki jonowe w ziarnie owsa w zależności od formy i dawki siarki. JCEA. 2013; 14(1): 114-123. http:// dx.doi.org/10.5513/JCEA01/14.1.1167

34. Dietz K J. Leaf and chloroplast development in relation to nutrient availability. J Plant Physiol. 1989; 134: 544-550. http://dx.doi.org/10.1016/S0176-1617(89)80145-2

35. Ku mar A R, Kumar R. Studies on the efficacy of sulphate of potash (SOP) on the physiological, yield and quality parameters of banana cv. Robusta (Cavendish-AAA). EurAsia J BioSci. 2008; 2(12): 102-109.

36. Jamal A, Moon Y-S, Abdin MZ. Sulphur-a general overview and interaction with nitrogen. Australian Journal of Crop Science (AJCS). 2010; 4(7):523-529.

37. Yadav BK. Interaction effect of phosphorus and sulphur on yield and quality of clusterbean in typic haplustept. World J Agric Sci. 2011; 7(5): 556-560.

38. Tkaczyk P, Chwil S. Formy i frakcje fosforu mineralnego w glebie nawożonej nawozami mineralnymi i obornikiem. Ann Univ Mariae Curie-Skłodowska, E Agric. 2004; 59(4): 1723-1730.

39. Griffiths MW, Kettlewell PS, Hocking TJ. Effects of foliar-applied sulphur and nitrogen on grain growth, grain sulphur and nitrogen concentrations and yield of winter wheat. J Agricult Sci Cambridge. 1995; 125: 331-339. http://dx.doi.org/10.1017/S0021859600084835
40. Hussain Z, Leitch MH. The effect of applied sulphur on the growth, grain yield and control of powdery mildew in spring wheat. Ann Appl Biol. 2005; 147: 49-56. http://dx.doi.org/10.1111/j.1744-7348.2005.00007.x

41. Kaczor A, Zuzańska J. Znaczenie siarki w rolnictwie. Chemia. Dydaktyka. Ekologia. Metrologia. 2009; 14(1-2): 69-78.

42. Eriksen J, Nielsen M, Mortensen JV, Schjorring JK. Redistribution of sulphur during generative growth of barley plants with different sulphur and nitrogen status. Plant Soil. 2001; 230: 239-246. http://dx.doi.org/ 10.1023/A: 1010328115203

43. Bartnikowska E, Lange E, Rakowska M. Ziarno owsa - niedoceniane źródło składników odżywczych i biologicznie czynnych, Cz I Ogólna charakterystyka owsa. Białka, tłuszcze. Biul Inst Hod Aklim Rośl. 2000; 215, 209-222.

44. Brink M, Belay G. Cereals and pulses. PROTA Foundation/Backhuys Publishers/CTA Vageningen, Netherlands. 2006: 300.

45. Wróbel E. Wpływ nawożenia azotem na plonowanie i jakość białka ziarna jęczmienia jarego i owsa uprawianego na paszę. Zesz Nauk ART Olsztyn. 1993; 56: 1-53.

46. Pisulewska E. The effect of increasing nitrogen fertilization levels on the yield, protein content and amino acid composition of winter triticale grain. Fragm Agron. 1995; 3 : 87-95.

47. Majcherczak E, Kozera W, Nowak K, B arczak B. Zawartość aminokwasów w ziarnie owsa nawożonego saletrą amonową z dodatkiem mikroelementów. Biul Inst Hod Aklim Rośl. 2006; 239: 117-122.

\section{Badanie wpływu dolistnego dokarmiania w warunkach zróżnicowanego nawożenia doglebowego na strukturę plonu i jakość owsa zwyczajnego (Avena sativa L.)}

\section{Streszczenie}

Badania przeprowadzono w oparciu o doświadczenie polowe, założone na glebie średniej (pył gliniasty), bardzo kwaśnej. Schemat doświadczenia obejmował 4 warianty nawożenia doglebowego: O, NPK, NPK $+\mathrm{MgSO}_{4} \times 7 \mathrm{H}_{2} \mathrm{O}, \mathrm{NPK}+\mathrm{CaO}+\mathrm{MgO}$ oraz 3 obiekty dokarmiania dolistnego: $\mathrm{O}_{(\mathrm{H} 2 \mathrm{O})}$, Insol PK $+5 \%$ roztwór mocznika, Ekosol U. Rośliną testową był owies odmiany 'Kwant'. Celem badań była szczegółowa charakterystyka reakcji owsa na dolistne dokarmianie w warunkach zróżnicowanych wariantów nawożenia gleby związkami wapnia i magnezu. Zastosowane czynniki doświadczenia zwiększały wskaźniki plonowania oraz różnicowały zawartość składników w ziarnie i słomie owsa. Nawożenie doglebowe w większym stopniu kształtowało parametry jakościowe plonu głównego niż stosowane w badaniach nawozy dolistne. Najlepsze 
efekty produkcyjne i jakościowe w uprawie owsa uzyskano po zastosowaniu $\mathrm{MgSO}_{4}$ i wapna magnezowego. Dolistne dokarmianie również korzystnie wpłynęło na cechy ilościowe i jakościowe plonu. Z zastosowanych nawozów Insol PK wykazywał lepsze działanie niż Ekosol U, szczególnie w kształtowaniu struktury plonu i składu aminokwasowego białka.

Handling Editor: Elżbieta Weryszko-Chmielewska

This is an Open Access digital version of the article distributed under the terms of the Creative Commons Attribution 3.0 License (creativecommons.org/licenses/by/3.0/), which permits redistribution, commercial and non-commercial, provided that the article is properly cited.

CThe Author(s) 2014 Published by Polish Botanical Society 